\title{
Setting up a traveling reserve reference collection
}

\author{
By Susan Doughty Raschke
}

\section{A practical solution to the accessibility problem}

$\mathbf{R}$ egis University's extended campus course offerings include a non-traditional MBA program offered through the School of Professional Studies and geared to the needs of working professional adults. Students complete ten courses from six different areas of emphasis. Two courses per 14-week semester are usually taken at a time, with each class meeting once per week.

The MBA program is increasingly being offered to small communities that do not have convenient access to academic libraries. A solution was needed to make the library services for these users "equitable with [those] provided to the on-campus community."

\section{Analyzing the problem}

A courier/FAX service is already available for regular circulating materials and interlibrary loan. But what about non-circulating reference materials? Many of the MBA extended campus students needed to be able to consult various reference tools on a regular basis; faxing of a few pages would not meet these user's needs.

Ideally, it would be advantageous to have a collection of materials available at each location, but space and financial restraints prevent this option. Classes are typically small and rotated throughout communities on about a twoyear cycle or whenever there are enough students interested to begin a session. A permanent collection cannot therefore be justified.

Dayton Memorial Library has successfully served the special needs of patrons in prisons through a traveling reserve collection; thus the idea of the "traveling reference reserve collection" was conceived. Regis has initiated several formal cooperative agreements between its academic library and extended site public or community college libraries to provide a variety of library services that include operating a reserve desk for students. The traveling collections could either be housed at 1) a nearby public or community college library; 2) an offsite Regis location with an administrative staff; or 3) with the professor teaching the course.

\section{The solution: Step by step}

A meeting with the dean of the School for Professional Studies ensured support for the traveling collection. In addition, the dean offered to see that courses at the various extended sites are scheduled so that the same course is not taught at two remote locations during the same time period until such time that more than one traveling collection can be supported.

To decide which items should be included in the collection, several key MBA faculty members were consulted as well as the librarian directly responsible for business reference collection development.

To save funds, an agreement was made with the Reference Department for certain serial purchases to add newest updates to the on-campus reference collection, and move the newly outdated serial to the traveling collection. For example, Standard \& Poor's Industry Surveys is received quarterly; the traveling collection will receive the newly outdated quarterly issues. Students may call toll-free to the reference desk of the on-campus library for assistance, so it was decided that all the materials in the traveling collection would be duplicates 
of titles held in the regular business reference collection.

A preliminary list of titles was generated. All MBA faculty were then sent a letter explaining why the traveling collection was being developed along with a list of the items already suggested. Faculty were asked to identify by course title which of the items supported the needs of the courses they currently taught and to supply information about other items that they felt were necessary to add to the collection or desired for the future. Fifty-six percent of faculty responded to the questionnaire.

The list of titles was ordered. As the materials came in, they were processed in such a way that they were identified as copies to the main collection, and checked out indefinitely to extended campus operations. If the materials are not in use at an extended site they can be checked back in, used, and housed at the main library facility.

\section{In practice}

As the semester schedule of courses becomes available, the extended campus librarian checks the course offering against the list of reserve items needed to support the course previously provided by the MBA professor. Telephone follow-up ensures feedback from professors about new courses or those that were not included in the survey. Cooperating public or community college libraries, facility coordinators, or professors are contacted at each remote site and arrangements made to place the items on reserve and to collect usage statistics.

Usage statistics will be important feedback tools. Some more heavily used titles may need to be ordered in duplicate. For example, Price Waterhouse donated a set of the handy Doing Business In . . guides which provide an understanding of the business environments of various countries. In the survey, professors indicated that the guides would be useful to at least seven different courses.

A permanent budget allows serial titles to be renewed and new items to be added to the collection as appropriate. Approximately $75 \%$ of the collection includes serials and government documents that will need to be purchased on a continuing basis. The budget for the collection is expected to remain near the same each year, with a percentage added annually to reflect price increases.

Reference services at the main campus library support the collection through toll-free telephone, e-mail, and fax for 80 hours of a 95hours-per-week schedule. When special assistance is needed, the extended campus librarian is available to provide bibliographic instruction at the remote site classroom or by telephone.

To publicize the collection, the extended campus newsletter distributed to faculty, administrators, and students identifies new holdings that are added to the traveling collection. Faculty receive a list of which items have been ordered to enhance the courses they are teaching, and are contacted on a regular basis to ensure that the collection remains up-to-date.

\section{Conclusion}

The traveling collection is one of a number of ways librarians have found to successfully support extended campus students. The collection also provides a solution for some of the accreditation concerns raised by Howard L. Simmons such as accessibility to library resources by extended campus patrons. ". . . some accreditors insist on discrete on-site library collections for all off-campus programs, most encourage and will allow alternatives as long as they are comparable to those available to oncampus students." In 1990 the Taskforce to Review the Guidelines for Extended Campus Library Services found that most agencies were not yet aware of the ACRL guidelines. Although there are currently no published norms against which extended campus library service programs are measured, ${ }^{3}$ extended campus librarians must promote the guidelines and assess how well their institutions meet them. As extended campus librarians work with their accrediting agencies, such norms should evolve. The process described above may be used as a model for other remote-site programs seeking to improve library support to extended campuses.

\section{Notes}

${ }^{1}$ Association of College and Research Libraries, Task Force to Review the Guidelines for Extended Campus Library Services (1990), "ACRL Guidelines for Extended Campus Library Services," CERL News, 51, (April 1990): 354.

${ }^{2}$ Howard L. Simmons, "Accreditation Expectations for Library Support of Off-Campus Programs," Library Trends, 39, (Spring 1991): 396.

${ }^{3}$ Lynn LaBrake-Harrison, "Extended Campus Library Services: Guidelines or Standards?" Library Trends, 39, (Spring 1991): 385. 


\section{TECHNOLOGY FOR THE 90's AND FOR THE LIBRARIES OF TOMORROW}

\section{BLACKWELL'S PROUDLY INTRODUCES...}

\section{FOR COLLECTION DEVELOPMENT}

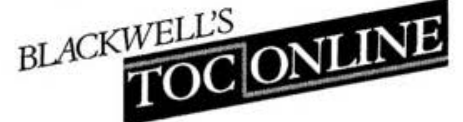

Blackwell's New Titles Online database now includes Tables of Contents and Descriptive Summaries for new and forth-coming scholarly monographs.

- Browse the contents pages before placing the order

- View the publisher's title description

- Order the title electronically

- Insure a title is included on approval

- Access through the INTERNET

\section{FOR PUBLIC ACCESS CATALOGS BLACKWELL'S 505}

Blackwell's MARC With Books ${ }^{\circledR}$ service now offers LCMARC records enriched with Tables of Contents.

- Enhance subject access

- Improved chapter-level author access

- View contents \& summaries in your PAC before searching the shelves

- Increase interlibrary loan efficiency

FIND OUT HOW EASY AND COST EFFECTIVE IT CAN BE TO GET CONTENTS INFORMATION TO BOTH YOUR STAFF AND PATRONS TODAY!

\section{BLACKWELL \\ NORTH AMERICA, INC. \\ TECHNICAL SERVICES DIVISION}

6024 SW Jean Road, Building G, Lake Oswego, Oregon 97035. Telephone: 503-684-1140 Fax: 503-639-2481 